\title{
Preoccupations of Some Asian Australian Women's Fiction at the Turn of the Twenty-first Century
}

\author{
Carole Ferrier
}

The University of Queensland

\begin{abstract}
This paper offers a look back over the rise of the visibility, and the rise as a category, of Asian Australian fiction from the beginning of the 1990s, and especially in the twenty-first century, and some of the main questions that have been asked of it by its producers, and its readers, critics, commentators and the awarders of prizes. It focuses upon women writers. The trope of "border crossings"-both actual and in the mind, was central in the late-twentieth century to much feminist, Marxist, postcolonial and race-cognisant cultural commentary and critique, and the concepts of hybridity, diaspora, whiteness, the exotic, postcolonising and (gendered) cultural identities were examined and deployed. In the "paranoid nation" of the twenty-first century, there is a new orientation on the part of governments towards ideas of-if not quite an imminent Yellow Peril-a "fortress Australia," that turns back to where they came from all boats that are not cruise liners, containerships or warships (of allies). In the sphere of cultural critique, notions of a post-multiculturality that smugly declares that anything resembling identity politics is "so twentieth-century," are challenged by a rising creative output in Australia of diverse literary representations of and by people with Asian connections and backgrounds. The paper discusses aspects of some works by many of the most prominent of these writers. In its mediation, through similar-but-different travelling women's eyes, of the past and present histories of different national contexts, Asian Australian fictional writing is a significant and challenging component of the "national" culture, and is continuing to extend its audiences within, and beyond Australia.
\end{abstract}

$\mathrm{T}$ his paper discusses the emergence into increasing visibilty, from the late 1980s in Australia, of literary representations of bicultural/multicultural/transcultural subjectivities in texts produced by writers-predominantly women-who came to be talked about, or designated, as Asian Australian. In 1996, Tseen-Ling Khoo commented upon "the dearth of critical work on Asian-Australian women writers" (1996) and outlined some of the surrounding conditions of its context of hoped-for development, as well as the growing number of new literary works. The rise of this "category" of the Asian-Australian from the 1990s as a field of writing was greeted with enthusiasm, and participated in by academics and critics including many who had, in earlier decades, developed new areas including postcolonial and racecognisant theory. Many among them had been instrumental in the dramatic rise in influence of Marxist and feminist, anti-racist and postcolonial approaches to literature and culture, associated with the movement politics of the 1960s-on, that produced a transformation both 
in critical methodologies and the texts that were promoted and published, away from the centrality of the white, middle class, ostensibly heterosexual man. Some working in a critical Australian Studies that had begun to problematise the frequently narrow nationalism of that area also welcomed the developing new recognition of the category of the Asian Australian.

At the turn of the century, there were several collections of articles that provide some indication of the then state, and impact, of the new field of Asian Australian writing. In 2000, Helen Gilbert, Tseen-Ling Khoo and Jacqueline Lo edited Diaspora: Negotiating Asian-Australia, to which they also wrote an Introduction, "New Formations in Asian-Australian Cultural Politics" (2000). In 2001, in a "Focus on Asian Australian Writing," Hecate published four articles: one by Peta Stephenson (on Indigenous/Chinese interaction, historically and more recently); one by Shen Yuanfang on two women's novels, Shanghai Baby and Mistaken Love (texts that were seen as daring in the Chinese community, both mainland and expatriate); and two articles on Simone Lazaroo's second novel, The Australian Fiancé (2000)—two contextualised readings of it within politicised, cross-disciplinary postmodern frames, with Olivia Khoo focusing upon the concept of the ornamental and Robyn Morris focusing upon photography. Also in 2001 appeared Bastard Moon: Essays on Chinese Australian Writing. Wenche Ommundsen's Introduction suggested: "While not all of Chinese-Australian writing is political in a narrow sense, it almost inevitably engages with issues of political import" (Ommundsen, 2001 , p. 2). It also stated that while among those included, "some (like the editor) have no specialist knowledge of Chinese language and culture and approach the writing from an Australian or international perspective, examining its place within multicultural and diasporic traditions," there was also a strong sense of having an Asian-Australian or, often, a ChineseAustralian identity on the part of a number of the contributors (p. 2). Alison Broinowski surveying the area in 2002 in an article from an earlier paper, concluded that "the face of Australian fiction about Asia changed in the 1990s," as did "the faces of those writing it"; she also noted that "the new faces are predominantly Asian Australian and female" (Broinowski, 2002 , n.p.).

This all sounds positive, as though things were going forward then. An Australia Council Report by Santina Bertone et al., for 2000 had struck a rather different note:

There can be little doubt that the public consensus on the benefit of multiculturalism that reached its height at the end of the 1980s has been shattered ... the conservative end of town has never been really comfortable with the idea that the Anglo-cultural hegemony in Australia should be eroded. (Baranay, 2004, p. 128)

But by 2012, a decade later, as Nicholas Jose discreetly points out in relation to Asian Australian literature, the writing "doesn't necessarily foreground any Australianness" (Jose 2012, p. 2)-by which he may well mean: these texts are not centrally preoccupied with the subjectivities of (constructed as typical) white Australians, or the world seen through their eyes. That same year, Ommundsen attributes the striking visibility and strength of Asian Australian writing to a number of factors: it had "grown rapidly since the first influx of refugees from post-war Vietnam"; also, "Asian Australian refugees have a higher level of education than the Australian population as a whole . . . and while many first-generation migrants especially those from Vietnam and mainland China, arrived with little English, migrants from countries like India, Sri Lanka, Singapore and Malaysia often had native or near-native proficiency"; in addition: "For the second and '1.5' generations of migrants who are currently coming onto the 
scene, language and education present no barrier" (p. 1). Accordingly, "(perhaps) inspired by an 'Asian boom' in diasporic cultural production across the globe, they have enthusiastically turned to writing as well as other art forms ... in many cases with considerable success" (Ommundsen, 2012, p. 1).

These Asian Australian texts generated stimulating critical commentary on their mediation of a gaze that was not the conventional, usual perspective upon "the alien," and an engagement with diaspora or with border crossings-both physical and in the mind on the part of authors/their characters that involved a negotiation with/of other subjectivities. The twentiethcentury texts quite frequently draw out some of the operations of gender and whiteness in specific spatial, national contexts, and particularly the performance of travelling identities, through which subjectivities_-Asian," but also distinctively glocal: Eurasian, Singaporean, Malaysian, mainland Chinese, Hong Kong, Taiwanese, Vietnamese, Indonesian, Filipino, Sri Lankan and more-come to be combined with Australian in new taxonomic conjunctions, that undermine or contest the previous, underlying hierarchical binary of whiteness (and often, a patriarchal and postcolonising capitalism as the basis of these social relations). In 2003, Andrew Jacubowicz described Australia as "a state with imperial contradictions": the rulers of this satrapy must "defend the nation against external competing empires, and . . ensure total acceptance of the empire within" (2003, p. 345). His metaphor of hard shell and soft centre encompasses a rising neoliberalism's stance against any threats to patriarchal capitalism's hegemony, while it managed "a more communal inward looking locality" (p. 345) that was the everyday experience of large numbers of the population.

In Britain (from whence the original Anglo-Celtic immigrants came-or were transported), the term "Asian-British," Snéha Khilay suggests, "implies a dual identity . . . evokes questions regarding which side of the hyphen the person belongs to, giving the impression that the person is oscillating between two cultures," (Khilay, 2012, n.p.). In Australia the hyphenation of the term, Asian Australian was gradually dropped, perhaps indicating that the new category was not necessarily an assimilation. ${ }^{1}$ On the pathway through the surrounding context of the emergence of more visibility for this "Asian" multicultural or transnational writing, the historical exclusion (actual/symbolic) of the Asian is visible as a prominent feature, along with the assertion of a particular economic and culturally specific power held over all non-whites by the British Australian (a rarely used term given that, as whiteness studies asserts, pressures to retain the Anglo-Celtic as normative are still quite widespread in this particular former colony). Looking back, the passing of the Immigration Restriction Act of 1901 was a key moment in instituting the White Australia Policy that lasted until 1966, when the Migration Act came into effect. The new Whitlam government removed race as a factor in immigration provisions in 1973. This followed on historically from the termination of South Sea Islander immigration as indentured labour particularly on the sugar cane fields, brought to work there from the 1870s, and returned or deported in the lead-up to Federation in 1905/6 (see Ferrier (2008) for discussion of some of the fictional representations by both black and white writers), as well as a long earlier history of Chinese workers on the goldfields, as cooks, and in market gardening and other businesses-that the government endeavoured to keep "small" (see Evans, Saunders \& Cronin (1975) for a Queensland history of the three main racially-defined groups).

\footnotetext{
${ }^{1}$ It was, however, also the case that hyphens began to be abandoned by publishers around the time of the $4^{\text {th }}$ edition of the OED in 1984.
} 
In a new emphasis again, some Australian Indigenous writers, notably Alexis Wright with Plains of Promise (1998) and The Swan Book (2012), add a different kind of challenge to white Australia, in the gaze upon the "alien" postcolonising European regime by significant Chineseancestry characters who live among Indigenous communities (see Stephenson, $(2001,2007$ ); Ferrier, $(2017,2018))$. Wright's authorial strategy has been to develop a pervasively ironic tone in her fiction-and a sardonic, sharp satire similarly often informs the Asian Australian texts; Broinowski notes, for example, of four Sri Lankan immigrant writers with whom she is familiar: "All look both ways, seeing ignorance and prejudice in both societies, and all, apart from Lokugé, enjoy even-handedly satirising them" (Broinowski, 2012, n.p.).

In the twenty-first century, texts that can be placed in the Asian Australian category are now also increasingly created by/about people who were born in Australia (with Asian parents or grandparents); these, accordingly, offer interesting variants upon "belonging" to the eccentric and unique, white national(istic) formation that is called "Australia"-as well as different answers to the "where are you from?" question, in that they have not had to request their citizenship.

In the 1960s, Multiculturalism had been instituted as official Australian policy, supposedly eroding the white, Anglo-Celtic supremacy imposed since the beginnings of colonisation, that had meant overt discrimination (for which the term then was "chauvinism") against various ethnicities, prosecuted with varying levels of determination. From the 1970s in Australia, there was a turn towards progressive militancy in support of socialism and equality, and this permeated many critical discourses. Multiculturalism was critiqued from the Left by various perspectives; in 1996 len Ang had suggested:

Processes of othering have been transformed in the multicultural era: racially and ethnically marked people are no longer othered today through simple mechanisms of rejection and exclusion but through an ambivalent and apparently contradictory process of inclusion by virtue of othering. (Ang, 1996, p. 37)

Katherine Hallemeir comments upon why multiculturalism has been said to have a "sedative politics" (Chow, 2002, p. 132); as analysed by the Canadian critic Smaro Kamboureli, it is that "it suppresses the reality of the antagonism that often undergirds the identification of difference, ethnicity and hybridity" (Hallemeir 2011, p. 126). While, as Olivia Khoo and Christopher Lee point out, the development of multiculturalism had a different context in the United States (Khoo, 2001, p. 69, Lee, 2010), in 1990s Australia, antagonism was very clearly articulated by the Liberal Prime Minister, John Howard, along with Pauline Hanson of the One Nation Party (see Curthoys \& Johnson, (1998)). After its apparent resurgence challenged the new assumed, developing ideologies of equality and tolerance ("liberal" expressions of which were critiqued by Ghassan Hage (1996), and by Chow (2002), in hopes then of something "better" being expected to arrive), the antagonists had sought some reinstatement of the previously understood superiority of European (centrally British) culture and traditions (centrally imperialist). "In 1996, a fiery-headed maiden declared in parliament that we were in danger of being 'swamped by Asians,' who 'have their own culture and religion, form ghettos and do not assimilate,"' wrote Alice Pung, in her original draft Introduction to a 2008 anthology of Migrant writing (see Low, (2015)). Howard also launched the "culture wars" against, for example, what he called the "black armband" view of the history of colonisation (powerfully 
represented by the History Department at James Cook University-where Eddie Mabo was from 1957 employed as a gardener and began to do research in the Library-as well as by historians from many other Universities including Queensland). Howard did not favour history that mourned the white invasion, or that protested about the colonial hegemony that had stolen Indigenous land and children and has continued to do so in the current period of supposed postcoloniality (or of "postcolonising"- the term that Aileen Moreton-Robinson (2003) prefers).

Earlier, in the new Multicultural writing, given space and a degree of endorsement by the new policies (Gunew, 2004), there are travels for a long or short period to another country or culture: some journeys are chosen, others are undertaken from various kinds of necessity or duress with the voluntary voyager being in a vastly different situation to the refugee, and generally having the option of returning to the familiar, original home. Further, as Rey Chow points out: "[a]s ethnic identities become part of a commodified global culture . . . there also remains an entrenched hostility toward those ethnics-often dispossessed, dislocated migrants who are poverty-stricken" (Chow 2002, p. 132). Class differences were and are apparent among the new Asian Australian writers but, often through connections to universities in Australia quite a number of them attained some economic security that helped them to become visible cultural figures. Many of those who have become prominent, studied and/or were employed in tertiary institutions, often in the burgeoning field of Creative Writinga new disciplinary area to which feminist methodologies with their central concerns with subjectivities and transdisciplinarity made a central contribution. Something of a publishing boom for Asian Australian writing was aided by some financial support for the writers from governmental Arts Departments and University Presses. Audiences were built from the new Creative Writing academic discipline, as well as from the new comparative literature courses being taught by Literature and Cultural Studies academics, and community activities including alternative bookshops, book clubs, launches and readings. An engaged politics remained widespread after the upsurges of movement and identity politics. There was also growing interest in reading-and sometimes theorising - "world" or transnational literature for the expansion of national horizons.

Theorisations of hybridity originally arose from taxonomies of racial or ethnic purity (Young, 1995), and the concept was also critiqued by Jacqueline Lo as tending to expect the manifestation of "happy hybridities,"--though, as she argued, this does not always require that identity be enjoyed as a confluence of difference; it can also be a site of contestation if it is an "intentional hybridity" (Lo, 2000, p. 154). Accordingly, the Eurasians, for example, that people many of the novels of the Western Australian novelist, Simone Lazaroo, ${ }^{2}$ may have mixedrace ancestry going back to white colonisers elsewhere. They may have experienced being "in-between" (Lazaroo, The World Waiting To Be Made 1994, pp. 259, 262) in the country in which they were born into a type of hybrid identity and then take on a further hybridness when they emigrate elsewhere. They may then be afflicted with "phantom limbs and cultural ventriloquism" (the title of a 2008 article by the Singaporean/Malaysian writer Hsu-Ming Teo), or subject to "coerced mimeticism"- the term used by Chow for "a process in which those marginal to mainstream western culture are expected to resemble and replicate the very banal perceptions ... to authenticate the familiar imaginings of them as ethnics" (Chow, 2002, pp.

\footnotetext{
2 See the Appendix for brief thumbnail sketches of the "backgrounds" of some Asian Australian fiction writers from the past twenty-five years or so.
} 
107, 142). Further, Chow argues, they are beset by the fantasy of the stereotype of "the Oriental Woman": "Both the orient and woman have been functioning as the support for the whiteman's fantasy, as the representation of the white man's jouissance" (Chow, 1998, p. 41).

The emerging "multicultural" Australian writers who were beginning to win prizes, perceived a difficulty in the influence, and the takeup of, earlier very successful Asian American writers (particularly Amy Tan-although they also included Maxine Hong Kingston who wrote the 1976 novel, The Woman Warrior, (Ferrier, 2013, pp. 6-8)). The Malaysian Australian writer, Beth Yahp, author of The Crocodile Fury (1992), reacted to the film adaptation of one of Tan's novels as depicting, "[a] perfect victim, as the American movie The Joy Luck Club demonstrated, two hours of that Other Asia's weeping face, one weeping woman's face after another, until they blur into each other. Straight off the boat, the Other Asia is that kind of victim too, staring through a hash of wire" (Yahp, 1996, p. 64). Hsu-Ming Teo wrote, ten years later:

However I may be perceived—alien Asian, invisible Australian, or otherwise-I am no victim. I will not play the politics of victimhood based upon an ascribed Australian identity. I will not take the multicultural high moral ground. (Teo, 2007, p. 139)

In 1997, Nicos Papastergiadis had suggested: "If the non-Western is to enter the Western, it must do so in the guise of the cultural hybrid: the non-western Westerner" (Papastergiadis, $p$. 264). Asian Australian women's positionality when articulated in their telling of Other stories, then, provides a lens for examining the complexity of diasporic belonging, through/against dominant, overlapping, racialised, Orientalist and patriarchal discourses, and in the context of national and transnational framings of them. It has been thought that there might be a move towards a cosmopolitanism perhaps, though this is also problematic if what one means by it is self definition in relation to the world outside, and a strategy for locating self and community in relation to it; since this is not easily achieved in a dramatically unequal society-let alone one with the Australian Constitution's insistence upon a single and pure affiliation with (oops) one nation, for anyone running for Federal parliaments. A rather unfortunate turning away of individuals with uncancelled "multicultural" affiliations produced in 2017 a decimation of Senators (then spreading to the MLAs), due to dual citizenship. Regarding this, Tim Hollo comments upon the contradictions produced by the construction of nationality that the Constitution was determined to prescribe:

Matt Canavan's statement that he had enjoyed "representing the mining sector" as resources minister is far more troubling than his familial connection to Italy. Sitting at the centre of it all, of course, is the heartbreaking injustice of the Prime Minister's rejection of the Uluru "Statement from the Heart" as not desirable. (Hollo, 2017, n.p.)

Lars Jensen had in 2008 suggested that the impetus for counter-narratives (particularly in relation to how they challenged the area of mainstream Australian Studies) had come from three "driving forces . . . radical feminist, Aboriginal or Asian Australian, because to challenge the nation is to insist on not just the (tolerated) presence of other narratives, but also on their necessarily deeply disruptive force" (Jensen, p. 549). The terms of the challenge to the (white) nation (generally subtle, but pervasive) are variously and differently mediated by the different Asian Australian writers. 
In 2008, Alice Pung had edited Growing Up Asian in Australia, with stories and poems by around fifty Asian Australians. Lian Low recalls how Pung agreed to edit down her combative Introduction so that the book would notionally be more acceptable to Victorian senior high school curricula and Borders bookshop customers. Peril magazine \#8 published her original Introduction afterwards-from which Low quotes:

Our outside identity oscillates between being a grave threat to white nationhood and being the obedient racial group least likely to offend, depending on the political climate. In 1996, a fiery-headed maiden declared in parliament that we were in danger of being "swamped by Asians," who "have their own culture and religion, form ghettos and do not assimilate." We were back to being the [Yellow] Peril again. (Low, 2015, n.p., my insertion)

In 2012, Dorothy Wang, another critic along with Rey Chow writing about current Chinese/Asian American writers - and, in the case of Wang, also Asian Australian ones-as well as the state of any diversity movement politics, said that she could observe "certain trends and movements towards shifting into a post-race_certainly post-identity mindset" (Wang, 2012, p. 2). The earlier emergence of Multiculturalism in Australia, (visibly engaged in then by mainly European migrants) and advocacy for the value of the non-Anglo-Celtic was in tune with the identity politics that were the basis of much organising for recognition and rights in the movements of the 1970s-on, that feminists said then were concerned with foregrounding issues of "race, class, gender and sexuality"; and they played an important part in the advancement and visibility of distinctly Other minorities, during Multiculturality. Indigenous people, at the time and after, expressed their own reservations regarding claims about discrimination against non-whites in Australia being a homogeneous matter, given their still substantially unacknowledged custodianship of the land before invasion.

Migrant identities had frequently been discussed from the 1970 s with some cynicism, ${ }^{3}$ in terms of the ways they were constructed in Australian society as surface stereotypes; William Bradley summarises these as three Cs or four Fs-customs, celebrations and cuisine, or, folklore, food, fashion and festivals, and proposes the addition of clothes to the first and flags to the second (Bradley. 2015, p. 6). Nonetheless, the depth and persistence of Other traditions in these areas, and the actual challenge they can pose to received notions of "Australian culture," continues to emerge in the Asian Australian writing.

Meditation, often with irony, upon the expression of identities recurs in Asian Australian fiction. Hsu-Ming Teo's second novel, Behind the Moon (2005), follows three central characters growing up in Sydney in the 1970s and 80s, who are very aware of their conflicted identities: they are all "outsiders" at school in Western Sydney, where "the multicultural reject group" of Vietnamese/African American Tien, Chinese Justin and the unwillingly Anglo-Celtic Gibbo, are friends. The fourth main character, Linh, travels from Vietnam as a refugee, years after her daughter Tien did. Justin's mother, Annabelle Cheong, holds a commemorative Dead Diana Dinner (not Annabelle's phrase) around 6 September, the date of Lady Di's 1997 funeral, to bring the families together. At the dinner (with disastrous attempts at contributions of food aimed at being multiculturally pleasing), Gibbo's father, Bob, drunkenly denounces Justin's

\footnotetext{
${ }^{3}$ The development of Chinatowns in Western cities, however, has been suggested to have an eye to a successful marketing of unusual exotic food, clothing and objects to local populations.
} 
homosexuality; this is partly in reaction to a speech Justin's father has made about how successfully their family has fitted into Australian society.

Tien's ancestry is part-American (as the daughter of a black American serviceman) and partChinese/part-Vietnamese through her mother, Linh, who stayed behind in Vietnam when Tien left on a boat for Australia with other family members. Emily Zong suggests of Tien's relationship with her mother: "Tien disparages her mother's culture as victimhood and ancient history, without any genuine understanding of Vietnamese history and culture" (Zong 2016a, n.p.); Tien is not cognisant of the shame and persecution her mother has undergone. Zong's view of the society that Teo's novel depicts is that, in it:

The author confronts a singularity of national meaning that still dominates the Australian cultural and political consciousness, and at the same time interrogates how the structural dominance of a racialised whiteness is re-centralised in neoconservative sites of class and culture. (Zong, 2016a, n.p.)

In Teo's first novel, Love and Vertigo (2001), the daughter character has a similar feeling about her mother's ancestry: "these Singaporean roots of hers, this side of her-and possibly me too-was unacceptable. I was determined not to belong, not to fit in, because I was Australian, and Mum ought to be Australian too" (Teo, 2001, pp. 2-3). Hoa Pham suggests that Teo's novel, along with Alice Pung's Unpolished Gem (2006), articulated a trope of "racial melancholia"; in the latter work associated with "the dissonance of expectations of living in a Cambodian family in the Australian environment" (Pham, 2010, n.p.). Pham, like Alice Pung and Julie Koh, was born in Australia. As a child in Tasmania, she was not "comfortable with the hyphen in my identity . . . in my primary school there were only three Asian people and two of them were me and my brother and so I didn't really get the sense of being Vietnamese and proud of it till later in my life" (Pham, 2010, n.p.). Visiting Vietnam for the first time in 1997, she initially felt "displaced . . . more Australian than Vietnamese," but after a while began to consider it as her "spiritual home" (Pham, 2010, n.p.), and sought out other Vietnamese artists and activists in Melbourne on her return.

The internalisation of external interpellations of diasporic subjects to acknowledge and perform gender and racial difference (based in one or more Other nations), and, more or less, on the premise of their recognised backwardness or inferiority, is called"coerced mimeticism" by Chow. Simone Lazaroo's first novel, The World Waiting to Be Made (1994), showed some of the everyday coercion towards complicity with this mimeticism-on the part of some of the characters. The un-named Eurasian narrator in this novel emigrated to Western Australia in her childhood in the mid-1960s. Her father is very strict and her female relations also interpret any sexuate expression as "too-eager-to-ripe" (Lazaroo, 1994, p. 171); the Eurasian girl spends her earlier life highly conscious of her problematically "of colour" body (Morris, 2012, p. 117). As Zong (2016b) points out, her white friend, Sue, patronises her when she looks for reassurance: "I always think of you as being such a dag ... It must be the Asian in you" (Lazaroo, 1994, pp. 106-7). When she is older, she embarks upon a self-Orientalisation and emulates, though with a degree of irony, the clothes and makeup of Mata Hari (Lazaroo, 1994, p. 119). Despite the narrator's attempt to perform an expected abject authenticity, this becomes parodic when her difference and femininity are seen as consumable items in the normative gaze of her white friends and her lover (Zong, 2017). Having qualified as a teacher, she is sent to a remote Aboriginal community, a part of the plot that, Robyn Morris suggests, 
allows Lazaroo to introduce aspects of the politics of "the triangulated and colour-based relationship between those of Asian, Aboriginal and Anglo-Celtic ancestry" (Morris, 2010, p. 118).

Lazaroo's second novel, The Australian Fiancé (2000) is set in an earlier period, just after the end of the Japanese occupation of Singapore in 1942-some time before the inception in Australia of Multicultural policies-and has as its main character a "young Eurasian woman," again un-named; she is the illegitimate daughter of a Malay woman and a white English father and, living with her impoverished mother, she is also constrained by the Catholic ideologies of their particular community. Adam Aitken suggests that Asian women have been "victims of multiple colonisations and processes of dismemberment from community ties," and that the Eurasian character in this book is "the 'invaded space' colonized three times, by the British, by the Japanese and then by the white Australian" (Aitken, 2002, n.p.). The character has been forced to work as a comfort woman under the Japanese occupation, and had a child with a Japanese father. Standing on the wharf in Singapore when a ship comes in, she meets the scion of an Australian pearl trading company and she later goes to Broome to visit his family as his potential wife. In Singapore, the tourist white man takes photographs, but as Morris argues, the "imperial white gaze is inherently schizophrenic in that it operates within the social as a strategy for defining, but also for resisting categorizations of otherness" (Morris, 2001, p. 87). The Eurasian woman in Fiancé is able, to some extent, to reverse the gaze-given that the story is mainly told through her-so that, through the ways in which the narrative seems to offer the character some potential for empowerment, "Lazaroo decentres whiteness and its ideology is made open to critique" (Aitken 2002, n.p.). Olivia Khoo's critique seems to me more incisive, especially in discussing the affect of the deaths of the un-named main protagonist's mother and daughter (and Deborah Madsen (2008) draws attention to self-killing as trope in other migrant women's writing). Resistance was rarely effective in the power and gender relations of the time-and this romance does not end happily, since the pearler's very rich parents are determined that no marriage will take place. When the un-named "fiancée" from Singapore first meets them, the mother brings expensive white bedlinen-from an English firm, but embroidered in Singapore with the monogram of "Elsewhere" the name of the family homestead. This seventy-years-ago parallel with Ivanka Trump's Asian suppliers for her clothing stores (Haas, 31 May 2017, n.p.), as the fiancé explains, is "some little Chinese ladies

... Cheap" (Lazaroo, 2000, p. 93). His father tells the couple that he knows all about what Asia is like: "Cheap as chips. But no quality . . A Ah well, son. You'll always be able to afford her." The un-named character has come into Australia on a certificate of exemption (and the fiancé assures the customs officer he will make sure she doesn't do anything "too foreign"; eventually, she is forced to return to Singapore. Aitken suggests:

Hybridity is a metaphor for the paradox of a split subject who believes that he or she might transcend this split, though Lazaroo's bi-cultural subject is highly conscious of how the transcendence of the racially defined nature of bi-culturalism needs new strategies. The value of ethnicity is constantly re-negotiated in a world where race and ethnicity won't go away. (Aitken, 2002, n.p.)

No "transcendence" is in the offing, though; the pearler is left maybe to console himself with the Indigenous maid with whom he previously had a sexual relationship: few "strategies" are 
available to non-white women in the face of Australian white supremacist, patriarchal capitalism, to produce a happy ending for any story of what was called, in earlier times, miscegenation.

The Malaysian critic, Shanthini Pillai discusses some of the complexities of the category of Asian Australian in relation to Teo's Love and Vertigo (2001). She considers whether the process of:

representation of the various subject positions that is perceived in the country that was once home hinge upon a dialectics of migration, nationhood, gender and ethnicity that is tied more closely to Australian ideals than they are to Malaysia. If this is found to be at the heart of the novel, would they then stand as indications of some form of affiliation with that which they now call home? If this is the case, then how would this figure in their status as chroniclers of the older country?" (Pillai, 2010, p. 3)

Pillai quotes Chow's discussion in Writing Diaspora of how "many 'third world' intellectuals who choose to live in the 'first world," function in "a post-colonial discursive space ... serving as providers of knowledge about their nations and cultures. The way these workers function is, therefore, inseparable from their status as cultural workers in diaspora" (Chow, 1993, p. 4). In relation to Teo's implied authorial ideology, Pillai suggests that "although Teo is often linked to her Malaysian roots, it becomes obvious that it is Singapore that is at the heart of this novel" (Pillai, 2010, p. 11). Pillai's notion of "the heart of [a] novel" has some relationship to the affect produced for its reader-a perception of heartfelt convictions that are part of the identity of the author, produced both by experiences and feelings/emotion. Tamara Wagner, discussing in 2012 the issue of perceived "authenticity" in relation to the diasporic writer, comments upon persisting "readerly expectations"-of "not merely verisimilitude, but an explicitly autobiographical element"- though she says this is not the same as Cynthia Wong's questioning of "the 'correctness' or 'authenticity' of 'Asian' detail," in works by diasporic writers. "Wong has accused Amy Tan of presenting 'a heavily mediated understanding of all things Chinese; the view of a US writer.' The real problem is much larger" (Wagner, 2012, p. 7). Madsen points out in relation to Love and Vertigo that:

As the narrative opened with Grace's reflections on her alienation as an "Australian" from her mother's Singaporean roots so, at the end, the narrative returns Grace to Singapore after her mother's funeral when she is able to reflect on her acceptance of "that part of me which is embedded here and refuses to wither away." (Madsen, 2008, p. 116)

This brings out also the issues of victimhood as a stereotype (especially when female relations of the main fictional protagonists die young or kill themselves), and the relationship of the migrant or refugee to their original culture (which can often be patriarchal, hierarchical and oppressive to women). It also puts in an interesting light the "ownership" (such as it is) by Australia of the writers that are signified, or claimed there as Asian Australian. Wagner's invoking of the "real problem" raises the wider issue of the specific makeup, the cultural and political habitus, of the nation states that are the point of departure and/or the point of arrival of the travelling women who write. For Wendy Hesford, nations "instanciate and empower certain aspects of transnationality and its imagined publics":

Transnational publics may be protean, but they are no less governed by rhetorical principles, hermeneutic methods, cultural forms and identifications, and national 
forms and imperatives . . transnational public spheres are bound to and intersect with national publics and their discourses. (Hesford, 2010, p. 61)

As well as considering clashes of transnational contexts, in relation to this we might want to consider the very different relative economic power and cultural capital of women in different national locations, connected also to their ethnicity and class, and their sexuate existence. All these things produce their experience of living or, indeed, of being a writer. Chi $\mathrm{Vu}$, who left Vietnam as a child refugee, writes:

If you take a sharp knife to dissect my heart for the grit and sludge of hatred and prejudice, you will find it there. If you carve my heart in search of the red blood and scented flesh of compassion, forgiveness and courage, you will find that there too. I am a prison of possibilities. (Vu, 2009, p. 1402)

Nicholas Jose opines that "writing produced in Australia by writers of Asian background ... is characteristically transnational in its sensibility, exploring human mobility and mutability in its sophisticated new century dynamism (Jose, 2012, p. 2). Needing to be taken into account here is the different experience of the author, if refugee rather than immigrant. A significant development in the surrounding context of Asian Australian writers was that from 2001 in Australia, refugee policy began to harden, far beyond what it was before. It was back in that year that the Norwegian cargo ship, MV Tampa, was refused entry to Australian-controlled waters after rescuing 438 people, mainly asylum seekers, from an Indonesian fishing boat, drifting in distress. The then Liberal government rushed to pass a Border Protection Bill that meant asylum seekers could not land; while this failed in the Senate, the Labor Party soon colluded with what came to be known as the Pacific Solution-that any refugees that got close to Australia would be sent to prison camps on neighbouring Pacific islands, awaiting assessment that rarely meant admission. In November 2017, 470 refugees still remaining in the camp on Manus Island abandoned by the Australian officials were left with no water, food or electricity since Australia denied any responsibility. The New Zealand Prime Minister, Jacinda Ardern, attempted in vain to persuade Turnbull, Bishop and Dutton that they should accept her offer to resettle 150 of the men: "I think that anyone would look at a situation like that and see the human face of what is an issue that New Zealand is in the lucky position of not having to struggle with," she said (Davidson, 2017, para. 16).

Michelle De Kretser, one of the more "successful" of the immigrant writers, has also weighed in strongly against current Australian refugee policy in an article entitled, "We Are Not Very Caring" in which, Brigid Delany reports:

she's appalled, particularly at the Labor Party, which she says has not provided opposition to offshore detention. We are not very caring as a society ... and part of this is that Labor has just really given up on a lot of its responsibilities. (Delaney, 2017 , n.p.)

De Kretser also insists that she is part of the Australian "we" or "us": "There was one early reader who said I have a really superior attitude to Australians. It made me think she didn't think I was Australian . . . The reason I feel free to critique is that I am us." (Delaney, 2017, n.p.).

The structure of De Kretzer's Questions of Travel (2012) for which she won the Miles Franklin award in 2013, juxtaposes two stories in a long novel. One is that of Laura Fraser, a white 
Australian who travels around for years as a tourist on an inheritance from her aunt; the other is that of Ravi Mendes, a Burgher Sinhalese who goes to Australia on a bridging visa after his wife is killed. The narrative tracks their lives, Laura's from the 1960s and Ravi's from the 1970s. Janet Wilson argues that De Kretser "creates a different image of migrant unbelonging" to that in the Teo or Lazaroo novels (that I also discussed above), in which, she suggests, "alienation is attributable to racism, intolerance or mild discrimination ranging from nonacceptance to affectionate exoticisation."

Ravi is unable to move beyond his historical circumstances to continue practising not-at-homelessness, he returns to Sri Lanka driven by the wish to recapture an earlier version of home and belonging, entering into a totalising horizon of identity, a form of revived ethnic essentialism, countering sensations of grief, absence, loss and distance with a belief in prior constructions of family and home. (Wilson, 2016, n.p.)

She also suggests that Ravi's "incomplete mourning has led to a state of melancholia ... the loss of his wife and son, and then the death of his mother while in exile, become conflated with the loss of his country" (Wilson, 2016, n.p.).

A rather sharper critique of De Kretser as implied author is offered by Chandani Lokugé, who focuses upon the picnic organised by two Ethiopian refugees to celebrate gaining Australian citizenship. "We are led to anticipate an exciting new interweave from this microcosm of disparate cultures"-Ethiopian, Chinese, and Anglo-Celtic, with Ravi--"meeting around a woven mat." But, she suggests:

The picnic does promise productive conversations across cultures, but De Kretser's initiatives are stillborn. . . . connections are ambivalent and transient. De Kretser effectively interprets and improvises the known and the familiar with regards to the personal losses that migrants endure in their adopted countries. We listen to the tangled stories of marginalised individuals lost between being and becoming. (Lokugé, 2016, n.p.)

Lokugé draws attention to how, by contrast, Bobis in The Solemn Lantern Maker (2008) "steers her characters to attain even fleetingly" what Paul Giffard-Forêt calls "the 'cosmopolitanism of the 'wretched'” (Giffard-Forêt, 2016, p. 599), "through moments of freely intersecting and parting" (Lokugé, 2016, n.p.). James Clifford in Traveling Cultures, Olivia Khoo suggests, was "attempting to dissociate the term cosmopolitanism from the mobility of the privileged ... . we should focus upon 'the ways people leave home and return [as the] enacting of differently created worlds, interconnected cosmopolitanisms'; of 'routes' rather than 'roots' or 'essences'” (Khoo, 2007, p. 49). This is also a central concern of De Kretser's novel, as is brought out in her interview with Alexandra Watkins (Watkins, 2016). Giffard-Forêt offers a complex reading of Lazaroo's Sustenance, set in Bali, in the Elsewhere Hotel, that provides a range of perspectives within which postcolonising operates in Bali through touristic travelling (Giffard-Forêt, 2016, pp. 597-600), and focuses upon the poverty of the Indonesian people engaged in "service industries" for the wealthy.

The characters who live together in Dao's boarding house in Australia in Chi Vu's Anguli Ma: A Gothic Tale (2012) are subject to their own colonial hauntings "as they deal with their demons in the years after arriving as "boat people"' (Jose, 2012, p. 6). Discussing one of her 
plays in an interview, Vu identifies features of postcoloniality and being "in between" that are also relevant to her novel:

The postcolonial gothic is a genre used to represent the "other"-where true "otherness" can neither be killed off nor assimilated. . . . the gothic emphasises the terror of this encounter, rather than "glossing over" differences. I also use the "uncanny" to describe being in-between two worlds-Australia and Vietnam. (Vu 2015, n.p.)

In Anguli Ma ( $\mathrm{Vu}, 2012)$, the character Trieu, who came on the boat to Australia with Dao, jokes to her: "In this country the dog eats the man," in relation to the hallucinatory visions that he has, including:

the dog had Anguli Ma's face attached to its furry neck ... the dog didn't answer but instead began to grow pointy ears: its face was rubbery pink like recently burnt flesh, and when Trieu looked up he saw that Anguli Ma now looked like the dog ... "Stop changing," he screamed. (Vu, 2012, p. 46)

Dao has tried to settle Anguli down; when the strange manifestations begin to happen, she rebukes him: "'What, are you stupid? . . . This is not our country" (p. 55). Dao finds one of her books that had disappeared, "with a lei or garland made of severed fingers" (p. 104). Anguli has stolen the money that Dao is in charge of for the Vietnamese group in the neighbourhood, and she is struggling to survive as a reliable member of the community. Dao feels "the terror of emptiness, of finding herself utterly severed from her ancestral land" (p. 86), in an unheimlich adopted country.

Teo wrote in 2014 of having a sense of presenting an "amputated self":

If I look inside myself I see the misshapen fragments of various jigsaw pieces belonging to different puzzles. The intellectual, cultural, social, spiritual, familial, emotional and psychological do not align. There are awkward gaps everywhere. Yet lately I'm beginning to believe that it is in these interstices-the spaces of tension between conflicting parts of my inward self, the outward (mis)recognition of the Asian-Australian Alien that is me-where creativity dwells. I write stories and complete the pieces of the puzzle that do not exist within me and cannot be found out there. (Teo, 2007, p. 137)

Teo suggests, however, that she has reached a position of some reconciliation with her fragmented identity. This paragraph ends: "I can live with this. Easily" (Teo, 2007, p. 137).

Indonesia and Vietnam, along with Sri Lanka and the Philippines are more prominent among places that may be becoming "marketable" for publishers-either as countries of origin for writers or their characters, or as "settings" that they (re)visit. Bobis suggested, in 2008, that the international reclame achieved in recent years by several Indian writers meant that other Indian writers might expect to be more "familiar" from grappling with a cultural context (and sometimes an alternative aesthetic) that powerful publishers' readers and prize judges had determined was competitively new, and considered to be acceptable and understand-able. She asserts:

An Indian story is marketable because of the Rushdies, the Mistrys and Roys who have paved the way for Indian literature's place in the international literary canon. Readers know this landscape now. (Bobis, 2008, n.p.) 
With a degree of recognition/admiration/adoption for study/prizes, and so on, Asian Australian women's writing continues to become more established. This makes the role of publishers, promotion, prizes and marketing more foregrounded. In an extraordinary satiric piece, Jane Rawson, long-time travelling journalist for Lonely Planet, presents a narrative of taking Julie Koh to lunch on 11 October 2017. It addresses the economics of Koh's hoped-for successful writing career:

"Of course it's notable that I was probably the first Sydney Morning Herald Best Young Australian Novelist to have never written a novel," she notes wryly . . . and asks for the fifth or sixth time whether I'm definitely paying for lunch. "Smart money is on my forthcoming collection, A Book Set Entirely in Singapore in the Future... winning the Miles Franklin. "I know, I know," she says as she waves away my insistence that the Miles can only be won by a novel that shows Australian life in any of its phases, "but those rules weren't made for me." (Rawson, 2017) ${ }^{4}$

Koh also informs her interviewer that she is engaged to a rich dentist (a course she says was advised by Amanda Lohrey), and after finishing their rather disgusting food at the Pancake Parlor (initially fortified by the liquor in Julie's flask), they head to the train station swigging companionably from a bottle of rum.

Some of the writers had been seeing publishers' views of what was marketable as an alternative exotic as potentially problematic for their art, as was the case with a group of papers published in 2008 from an Asian Australian Identities conference in Melbourne in June 2007. Merlinda Bobis, another now much-awarded and published writer discussed pressures to be commercially successful that she considered could compromise the aesthetic and/or the politics of her writing:

How can I, as migrant writer, be accepted on faith by this new home, Australia when it has its own sensibility, shaped by its own mythologies so alien to me? ... When you play into the market's game, you will inevitably betray the voice of your grandmother, or the boiling of the rice pot before rice cookers were invented. (Bobis, 2008b, p. 124$)^{5}$

Bobis came to Australia after living in the Philippines for thirty-one years, and voices some of the difficulty she was experiencing in "marketing my hyphenated sensibility" (2008b, p. 119); she quotes the wry reflection of the Mexican poet Octavio Paz on the market- "It knows all about prices, but nothing about values." Of the "audience" for diasporic literature, Bobis says: "Why not name the biggest fear? This is too alien" (p. 121). Western interest in the literature of the Other was imbued earlier with a mixture of temerity and deep curiosity about the unfamiliar within a frame of dominant Orientalist ideologies that prescribed traditional postcolonial/ postcolonising relationships. Lazaroo, in the same 2008 collection, commented

\footnotetext{
${ }^{4}$ See also, Susan Wyndham: "Let's say it up front: neither of the Sydney Morning Herald Best Young Australian Novelists for 2016 has published a novel. . . . We loosened the rules in 2009 to include Nam Le's virtuosic collection, The Boat. Since then, several collections have pushed their way to the top among the novels" (Wyndham 2016 n.p.). The Award for 2017, won by Koh, was judged by Wyndham, De Kretser and Matt McGuire.

${ }^{5}$ Local spiritualities or folk tales from the original culture are a feature of Bobis' writing in, for example, FishHair Woman (2012), as they are in Beth Yahp's The Crocodile Fury (1992) and Hoa Pham's Vixen (2000). Paul Giffard-Forêt is one critic developing an engagement with the articulation of Asian spiritualities (or, folklore and customs) in Asian Australian writing.
} 
upon how "Australian publishers' blurbs often tend to categorise Asian-Australian novels as stories about migration," and frequently "emphasis[e] a book's foreignness" rather than "Asian Australian authors' access to both Western and Eastern experiences . . . access to both the familiar and the foreign" (Lazaroo, 2008, p. 111).

This comment from Lazaroo about what is familiar and unfamiliar for authors also suggests a further question about their implied audiences-whom are they writing to or for? Bobis' reference to possible betrayal has two possible significations-that she might show a lack of awareness, literary or social, in mediating the culture of her own country of origin, or that she will give an inadequate representation of its difference to an audience that will eat rice-but preferably prepared with an elaborate and expensive domestic cooking gadget purchased for the modern western kitchen. Bobis adopts a more assertive stance in the discussion than does the perhaps more conciliatory Lazaroo, and insists upon her intention to keep her "own voice":

I will vacillate between the demands of the market and my literary, cultural and political convictions. But I will eventually keep my own voice and play with new voices. I will shed off the Asian Australian brand. (Bobis, 2008b, p. 124)

Difficulties in relating to the "Asian Australian brand" for a winter growing up in a contemporary Australia "waiting to be made" in a different image, are brought out in "Sight," a ludicly and lucidly, ironic story from Julie Koh's prizewinning book, Portable Curiosities (2016), female characters in the narrator's family have a Third Eye in different parts of their body. The character Tattoo Man urges the narrator to "use your special eye" (Koh, 2016, p. 2), but her mother is hostile to his influence, saying he is disturbed, a "crazy Chinaman . . Mrs Nolan says he's just out of a mental home ... I don't want the neighbours thinking Asians are all the same" (p. 10). The narrator's mother warns her: "The person that can see goddesses can also see devils ... That third eye is a curse. We will have to close it or put it out"' (p. 5). Her mother keeps up the pressure: "Your imagination is getting away with you. You better catch it before I do. Because if I get my hands on it I will strangle it'” (p. 10-11), and the narrator eventually goes into hospital to have her Third Eye removed (p. 14-15). This is an interestingly different kind of commentary on the pressures upon younger would-be writers trying to talk back in Asian Australian families_analogous to that recalled by bell hooks in her youth in the American South-or even to bite back against the surrounding society, as the Aboriginal writer Vivienne Cleven (2001) did with her first novel.

With international events of considerable duration, violence and mass destruction, the twentyfirst century has been so far a time of major dispersal of populations producing many millions of refugees, while a higher incidence of major weather and seismic events are also displacing populations, producing famines and floods. Warfare and international capitalist competition also contribute immeasurably to the devastation of the landscape and the misery of displaced peoples. In a context of the "rise of Asia," especially China, which has a rapidly developing economy, and is a major trading partner of Australia and America, there is a shifting relationship between Australia and other countries in the world-especially those in Asia where Australia is geographically situated. As a (still) white supremacist nation, relatively "powerful" in Oceania because of its economy and its military alliances to the (albeit declining) world powers of the US and the UK, it is problematically positioned in relation to the various countries of origin (many, former colonies of the UK and Europe) of the diverse "Asian" immigrants who have come to its shores. Asian Australian fictional writing, by those who have 
crossed its borders (for some time again now increasingly fortified against, in particular, those who are poor), is a highly significant and valuable part of cultural creation in Australia that rewards our attention, and encourages reflection upon past and present histories.

\section{References}

Ahmed, S. (Ed.). (2003). Uprootings/Regroundings: Questions of home and migration. London: Berg Publishing.

Aitken, A. (2002). Simone Lazaroo's Eurasian narrators [Blog post]. Retrieved from https://adamaitken.wordpress.com/research-articles/simone-lazaroo/

Aitken, A. (2008). Third culture kids and mad migrant mothers, or how to outgrow Amy Tan. Journal of Australian Studies, 32(4), 445-54.

Ang, C. G. (2011, September 29). Wind and water, by C. G. Ang [Blog post]. Retrieved from http://mukabukubuku.blogspot.com.au/

Ang, C. G. (2006). What is wrong with the Chinese? Hecate, 32(2), 162-170.

Ang, C. G. (1997). Wind and water. Milson's Point, NSW: Minerva; Random House

Ang, I. (2003). Together-in-difference: Beyond diaspora, into hybridity. Asian Studies Review, 27(2), 141-54.

Ang, I., Chalmers, S., Lau, L., \& Thomas, M. (Eds.). (2000). Alter/Asians: Asian-Australian identities in art, media and popular culture. Sydney: Pluto.

Ang, I. (1996). The curse of the smile: Ambivalence and the 'Asian' woman in Australian multiculturalism. Feminist Review, 52, 36-49.

Baranay, I. (2004). Multiculturalism, globalisation and worldliness: Origin and destination of the text. JASAL, 3.

Bobis, M (2004). Banana heart summer. Millers Point, NSW; London: Murdoch.

Bobis, M (2008a). The solemn lantern maker. Sydney: Pier 9.

Bobis, M (2008b). Voice-brand-niche: Marketing Asian-Australianness. Australian Humanities Review, 45.

Bobis, M. (2012). Fish-hair woman. North Melbourne: Spinifex.

Bobis, M. (2015). Locust girl. North Melbourne: Spinifex.

Bradley, W. (2013). Is there a post-multiculturalism? (Working Paper Series: Studies on Multicultural Societies, No. 19). Afrasian Research Society, Ryukoko University.

Braziel, J. E., \& Mannur, A. (Eds.). (2003). Theorising diaspora: A reader. Malden, MA: Blackwell.

Broinowski, A. (2002). The no-name Australians and the missing subaltern: Asian Australian Fiction. Retrieved from https://openresearchrepository.anu.edu.au/handle/1885/41894

Broinowski, A. (2009). An interview with Dr Hsu-Ming Teo. Antipodes, 23(2), 192-93.

Broinowski, A. (2012, March 31). Sad restlessness of migrant soul [Review of the book Softly as I leave you, by C. Lokugé,]. Sydney Morning Herald. Retrieved from http://www.smh.com.au/

Brook, S. (2008). Cultural capital and cultural diversity: Some problems in Ghassan Hage's account of cosmopolitan multiculturalism. Journal of Australian Studies 32(4), 50920.

Chew, S. W. (2009). [Review of the book The dispeller of worries, by Lau Siew Mei]. Asiatic 3(2), 118-120.

Chow, R. (1993). Writing diaspora. Bloomington and Indianapolis: Indiana University Press. 
Chow, R. (1998). Ethics after idealism. Bloomington and Indianapolis: Indiana University Press.

Chow, R. (2002). The Protestant ethic and the spirit of capitalism. N.Y.: Columbia University Press.

Cleven, V. (2001). Bitin' Back. St Lucia: University Queensland Press.

Clifford, J. (1992). Traveling cultures. In L. Grossberg, C. Nelson \& P. Treichler (Eds.), Cultural studies (pp. 96-117). Routledge.

Curthoys, A., \& Johnson, C. (1998). Articulating the future and the past: Gender, race and globalisation in One Nation discourse. Hecate, 24(2), 97-114.

Davidson, H (2017, November 2). Manus navy will remove detainees by force if necessary, base commander says. The Guardian. Retreived from https://www.theguardian.com/

De Kretser, M. (2013). Questions of travel. Crow's Nest, NSW: Allen and Unwin.

Delaney, B. (2017, November 11). "We are not very caring": Michelle De Kretser on Australian society. The Guardian. Retrieved from https://www.theguardian.com/

Demin, S. B. (2007). Once in Broome. Magabala Books.

Dirlik, A. (2004). It is not where you are from, it is where you are at! Place-based alternatives to diaspora discourses. In J. Friedman, \& S. Randeria (Eds.), Worlds on the move: globalisation, migration and cultural security (Vol. 6). (pp. 141-65). London: Tauris.

Dudek, D. (2005). Blood gashed and running like rain: A diasporic poetics in Dionne Brand's Another place: Not here and Simone Lazaroo's The Australian fiancé. Australasian Canadian Studies, 23(2), 39-54.

Evans, R., Saunders, K., \& Cronin, K. (1975). Exclusion, exploitation and extermination. St Lucia: University of Queensland Press.

Ferrier, C. (2008). Never forget that the Kanakas are men: Fictional representations of the enslaved black body. In M. F. Borch et al. (Eds.). Bodies and voices: the force-field of representation and discourse in colonial and postcolonial studies (pp. 205-23). Amsterdam: Rodopi.

Ferrier, C. (2013). Crossing borders and boundaries: Reading some contemporary Asian Australian women's fictions. In Comparative Literature: East and West 19(2), (pp. 1-17). Sichuan University. Sichuan University Press.

Ferrier, C. (2017). Chinese-Ancestry characters in the fiction of Alexis Wright. [Unpublished paper delivered at ASAL conference], Melbourne, July 10-14.

Ferrier, C. (2018), Mending the broken line: Alexis Wright's First Novel, Plains of Promise. In B. Wheeler (Ed.). A Companion to the works of Alexis Wright. Camden House. [Manuscript submitted for publication].

Friedman, J., \& Randeria, S. (Eds.). (2004). Worlds on the move: Globalization, migration and cultural security. London: Tauris.

Giffard-Forêt, P. (2014). Southeast Asian women's fiction and the globalization of 'magic.' Journal of Postcolonial Writing, 50(6), 675-87.

Gilbert, H., Khoo, T., \& Lo, J. (Eds.). (2000). Diaspora: Negotiating Asian-Australia. Special Issue JASAL, 24(65).

Giffard-Forêt, P. (2016). The root of all evil? Transnational cosmopolitanism in the fiction of Dewi Anggraeni, Simone Lazaroo and Merlinda Bobis. Journal of Postcolonial Writing. 52(5), 595-609. doi:10.1080/17449855.2016.1202561 
Gunew, S. (2004). Haunted nations: The colonial dimensions of multiculturalism. London and New York, Routledge.

Hage, G. (1998). White nation: Fantasies of white supremacy in a multicultural society. Sydney: Pluto Press.

Hallemeier, K. (2011). Writing hybridity: The theory and practice of autobiography in Rey Chow's The secrets of ethnic abjection and Brian Castro's Shanghai dancing. Antipodes 25(2), 125-30.

Hesford, W (2010). Cosmopolitanism as the geopolitics of feminist rhetoric. In E. E. Schell \& K. J. Rawson (Eds.). Rhetorica in motion: Feminist rhetorical methods and methodologies (pp.53-70). Pittsburgh: University of Pittsburgh Press,.

Hollo, T. (2017, November 17) Australia's ageing constitution is past its use-by date. Sydney Morning Herald. Retrieved from http://www.smh.com.aul

Hooks, B. (2014). Talking back: Thinking feminist, thinking black. Oxford: Routledge.

Jacobs, L. (2004). Tales of two cities: Fictions by Lau Siew Mei and Susan Johnson. Antipodes 18(2), 113-18.

Jensen, L. (2008). Locating Asian Australian studies. Journal of Australian Studies, 32(40), 543-52.

Jose, N. (2009). (Ed.) Macquarie PEN Anthology of Australian Literature. Crow's Nest: Sydney: Allen and Unwin.

Jose, N. (2012). Everyday and exotic: Australian Asian writing [Web Page]. Retrieved from https://www.wheelercentre.com/

Kamboureli, S. (2000). Scandalous bodies: Diasporic literature in English Canada. Wilfrid Laurier University Press.

Khilay, S. (2014, November 8). The politics of hyphenated identities [Blog post]. Retrieved from http://blogs.Ise.ac.uk/

Khoo, T. (1996). Who are we talking about? Asian Australian writers: An overview. Hecate 22(2), 11-30.

Khoo, T. (2001). Re-siting Australian identity: Configuring the Chinese citizen in Diana Giese's Astronauts, lost souls and dragons and William Yang's Sadness. In W. Ommundsen (Ed.). Bastard moon: essays on Chinese-Australian writing pp. 95110. Otherland Literary Journal, (7)

Khoo, T., \& Lo, J. (2008). Asia@Home: New directions in Asian Australian studies. Journal of Australian Studies 32(4), 425-32.

Khoo, O. (2001). Whiteness and the Australian fiancé: Framing the ornamental text in Australia. Hecate 27(2), 68-85.

Khoo, O. (2007). The Chinese exotic: Modern diasporic femininity. Hong Kong: Hong Kong University Press.

Koh, J. (2016). Portable curiosities. St Lucia: University of Queensland Press.

Lau, S. M. (1991). The mirror people. Hecate 17(2), 172-79.

Lau, S. M. (2000). Playing Madame Mao. Rose Bay, NSW: Brandl and Schlesinger.

Lau, S. M. (2009). The dispeller of worries. Selangor, Malaysia: Marshall Cavendish.

Langton, M. (2004). Response. In G. Greer, Whitefella jump up: The shortest way to nationhood (pp. 158-70). London: Profile Press,

Lazaroo, S. (1994). The world waiting to be made. Fremantle: Fremantle Arts Centre Press.

Lazaroo, S. (2000). The Australian Fiancé. Sydney, NSW: Picador. 
Lazaroo, S. (2005). Memorialising the lost past. In C. van Driesen, \& R. Crane (Eds.) Diaspora: The Australian experience (pp.433-38). New Delhi: Prestige Books.

Lazaroo, S. (2008). The Asian disease. In A. Pung (Ed.). Growing Up Asian in Australia. Melbourne: Black Inc.

Lazaroo, S. (2010). Sustenance. Crawley, WA: University of Western Australia Publishing.

Lazaroo, S. (2014). Lost river: Four albums: Lives and images lost and found. Crawley, WA: University of Western Australia Publishing.

Lau, L., \& Mendes, A. (2011). Introducing re-orientalism and South Asian identity politics: The oriental other within. London and New York: Routledge.

Lee, C. (2010). Asian American literature and the resistances of theory. Modern Fiction Studies 56(1), 19-39.

Lo, J., Chan, D., \& Khoo, T. (2010). Asian Australia and Asian America: Making transnational connections. Amerasia Journal 36(2), 13-30.

Lo, J., Khoo, T., \& Gilbert, H. (2000). New formations in Asian Australian cultural politics. In J. Lo, T, Khoo and H. Gilbert (Eds.). Diaspora: Negotiating Asian-Australia (pp.112). University of Queensland Press.

Lo, J. (2000). "Beyond happy hybridity: Performing Asian-Australian identities." In Ang et al., (Eds.), Alter/Asians: Asian-Australian identities in art, media and popular culture (pp.152-68). Pluto Press.

Lo, M. W. W. (1999). Shaking a few tales: The dialectics of hybridity and Beth Yahp's The Crocodile Fury. Hecate 25(1), 56-71.

Lokugé, C. (2000). If the moon smiled. Penguin.

Lokugé, C. (2003). Turtle nest. New Delhi: Penguin India.

Lokugé, C. (2012). Softly as I leave you. Sri Lanka: Bay Owl Press.

Lokugé, C. (2016). Mediating literary borders: Sri Lankan writing in Australia. Journal of Postcolonial Writing 52(5), n.p.

Low, L. (2015). Not another Asian-Australian anthology? Writers Victoria, 23 August 2015.

Madsen, D. (2006). No place like home: The ambivalent rhetoric of hospitality in the work of Simone Lazaroo, Arlene Chai and Hsu-Ming Teo. Journal of Intercultural Studies 27(1), 117-22.

Madsen, D. (2008). Bearing the diasporic burden. Representations of suicide in Sky Lee's Disappearing moon cafe, Fae Myenne Ng's Bone and Hsu Ming Teo's Love and vertigo. In A. R. Lee (Ed.). China fictions/English language: Literary readings in diaspora and after (pp.101-17). Amsterdam: Rodopi.

McFarlane, R. N. (2015). A bay of whispers: Seascape in Simone Lazaroo's The Australian Fiancé. Antipodes 29(1), 163-73.

Moreton-Robinson, A. M. (2003). I still call Australia home: Indigenous belonging and place in a white postcolonising society. In S. Ahmed (Ed.). Uprootings/Regroundings: Questions of home and migration (pp. 23-40). London: Berg Publishing.

Morris, R. (2001). Reading photographically: Translating whiteness through the eye of the empire. Hecate 27(2), 86-96.

Morris, R. (2006). Growing up an Australian: Renegotiating mateship, masculinity and 'Australianness' in Hsu-Ming Teo's Behind the Moon. Journal of Intercultural Studies 27(1-2), 151-66.

Morris, R. (2008). Food, race and the power of recuperative identity politics within Asian Australian women's fiction. Journal of Australian Studies 32(4), 499-508. 
Morris, R. (2010). Relations of difference: Asianness, indigeneity and whiteness in Simone Lazaroo's Fiction. Kunapipi 32(1-2), 16-29.

Ommundsen, W. (2012). Transnational imaginaries: Reading Asian Australian writing. JASAL 2, 1-8.

Ommundsen, W. (Ed.). (2001). Bastard moon: Essays on Chinese-Australian writing. Special Issue of Otherland 7.

Ouyang, Y. (2008). Chinese in Australian fiction, 1888-1988. Amherst, N.Y.: Cambria Press. Papastergiadis, N. (1997). Tracing hybridity in theory. In P. Werbner and T. Modood (Eds.) Debating cultural hybridity (pp. 257-81). London: Zed Press,

Patke, R., \& Holden, P. (2010). Southeast Asian writing in English. Oxford and New York: Routledge.

Pèrcopo, L. (2001). Presence and absence: The paradox of ghosts. An interview with Beth Yahp. Quaderni della Facoltà di Lingue e Letterature Straniere dell'Università degli Studii di Cagliari 3, 367-77.

Perera, S. (2005). Asian and Pacific inscriptions: Identities, ethnicities, nationalities. Melbourne: Meridian.

Pillai, S. (2007). Occidental echoes: Beth Yahp's ambivalent Malaysia. Hecate 31(1), 17489.

Pillai, S. (2010). Essentialism and the diasporic native informant: Malaysia in Hsu Ming Teo's Love and vertigo. GEMA Online Journal of Language Studies,10(1), n.p.

Pham, H. (2000). Vixen. Sceptre.

Pham, H. (2010). Racial melancholia in Brian Castro's Chinese-Australian historical fiction. Australian Literary Compendium 1.

Pung, A. (2006). Unpolished gem. Melbourne: Black Ink.

Pung, A. (2008). Growing up Asian in Australia. Collingwood, Vic: Black Ink.

Pung, A. (2011). Her father's daughter. Collingwood, Vic.: Black Ink.

Rawson J. (2017, October 11). Lunch with Julie Koh. Overland, Retrieved from https://overland.org.au/

Stanfield, R. (1994). A remarkably tolerant nation? Constructions of benign whiteness in Australian political discourse. Borderlands e-journal. 3(2), n.p.

Stephenson, P. (2001). Finding common ground: Indigenous and Asian diasporic cultural production in Australia. Hecate 27(2), 59-67.

Stephenson, P. (2007). The outsiders within: Telling Australia's Indigenous-Asian story. Sydney: University of New South Wales Press.

Teo, H. (2001). Love and vertigo. St Leonards, NSW: Allen and Unwin.

Teo, H. (2005). Behind the Moon. Crow's Nest, NSW: Allen and Unwin.

Teo, H. (2007). Amputations of the self. Life Writing 2, 129-39. doi:10.1080/10408308518278

Teo, H. (2008). Phantom limbs and cultural ventriloquism: Communicating cultural difference as a novelist. Journal of Australian Studies 32(4), 521-29.

Tucker, S. (2000). Your worst nightmare: Hybridised demonology in Asian-Australian women's writing. Journal of Australian Studies, 24(65), 150-57.

Tucker, S. (2001). Beyond belief: Representation and revolt in Lillian Ng's Swallowing Clouds. In W. Ommundsen (Ed.), Otherland Literary Journal 6, 125-44. 
Vu, C. (2009). Vietnam: A psychic guide. Footscray Community Arts Centre [2001]. Reprinted in N. Jose (Ed.), Macquarie PEN anthology of Australian literature, pp.1398-1402.

Vu, C. (2012). Anguli Ma: A gothic tale. Artarmon, NSW: Giramondo.

Vu, C. (2015, August 13). Interview with Chi Vu (Playwright): The dead twin. Retrieved from http://theatreworks.org.au/

Wagner, T. (2012). Hours of morbid entertainment: Self-irony and replayed cliches in HsuMing Teo's fiction. JASAL 12(2), 1-9.

Wang, D. (2000). The making of an "Australian" self in Simone Lazaroo's The world waiting to be made. Journal of Australian Studies, 24(65), 44-49.

Wang, D. (2012). Does Anglophone Chinese diasporic avant-garde writing exist? JASAL 12(2), 1-17.

Watkins, A. (2016). Tourists, travellers, refugees: An interview with Michelle De Kretser. Journal of Postcolonial Writing. 52(5), n.p.

Wilson, J. (2016). (Not) being at home: Hsu Ming Teo's Behind the Moon (2005) and Michelle De Kretser's Questions of travel (2012). Journal of Postcolonial Writing 52(5), n.p.

Wilson, J., \& Lokugé, C. (2016). Introduction. Realigning the margins: Asian Australian writing. Journal of Postcolonial Writing. 52(5). n.p.

Wong, S. C. (1995). Denationalisation reconsidered: Asian American cultural criticism at a theoretical crossroads. Amerasia Journal 21(1-2), 1-27.

Wyndham, S. (2016, November 2). The Sydney Morning Herald Best Young Australian Novelists Awards Turn 20. Sydney Morning Herald. Retrieved from http://www.smh.com.au/

Yahp, B. (1992). The crocodile fury. Pymble, NSW: Angus and Robertson.

Yahp, B. (1996). Place perfect and the other Asia. Westerly 41(1) (Autumn), 61-71.

Yahp, B. (2015). Eat first, talk later. North Sydney: Random House Australia.

Yahp, B. (2017). The red pearl and other stories. Newton, NSW: Vagabond Press.

Young, R. (1990). White mythologies: Writing history and the west. N.Y.: Routledge.

Yuanfang, S. (2001). Sexuality in east-west encounters: Shanghai baby and Mistaken love. Hecate, 27(2), 97-105.

Zong, E. Y. (2014). The plague of love. [Review of the book Locust girl: A lovesong by M Bobis]. Australian Women's Book Review 26(1 \& 2), 28-31.

Zong, E. Y. (2016a). I protest, therefore I am: Cosmo-multiculturalism, suburban dreams, and difference as abjection in Hsu-Ming Teo's Behind the Moon. Journal of Intercultural Studies 37(3), 234-39. doi:10.1080/07256868.2016.1163535

Zong, E. Y. (2016b). Unlearning othering: Asian Australian and Asian American women's fiction (PhD Dissertation). The University of Queensland.

Zong, E. Y. (2017). Rethinking hybridity. Amputated selves in Asian diasporic identity. In T. Clark et al., (Eds.) Worldmaking: Literature, language, culture (pp.189-200). Philadelphia, Pennsylvania, USA: John Benjamins.

\section{Appendix}

\section{Short Biographies of some Asian Australian Women Creative Writers Publishing Fiction in the Twenty-First Century}


Chin Geok Ang was born in Singapore in 1942. She did an Honours degree at The University of Queensland and stayed in Singapore for several years before returning to Australia to do a Masters in Creative Writing at Macquarie and a PhD at Queensland in 2011. She has published a biography of Aung San Suu Kyi (1998), and some fiction.

Merlinda Bobis was born in 1959 and grew up in the Philippines. She taught in Universities there for ten years and then completed a Doctorate of Creative Arts at the University of Wollongong, where she taught for twenty years. Bobis's prose, poetry and essay writing work is widely published and 9 dramatic works have been performed in countries around the world. She has received many major prizes for her fiction; notably the Christina Stead and NSW Premier's in 2016 for Locust Girl (2015); 2013 MUBA for Fish-Hair Woman (2012); Steele Rudd for White Turtle as well as several Philippine literary awards. She is currently at the ANU in Canberra on an Honorary research appointment.

Julie Koh was born in Sydney to Chinese Malaysian parents. She studied Politics and Law at the University of Sydney, and gave up Law to pursue writing. Her Portable Curiosities (2026) received prizes and shortlistings including the SMH Best Young Australian Novelist award; her stories have been widely published and short films based upon them screened at several film festivals. She is editor of BooksActually's Gold Standard 2016 and a founding member of the experimental collective Kanganoulipo.

Michelle De Kretser was born in 1957 in Sri Lanka , moved to Australia in 1972 when she was 14 , and grew up in Melbourne. She gained a Masters degree in Paris, and worked for Lonely Planet. She has published several novels that have won many Australian prizes, including the Miles Franklin award in 2013 for Questions of Travel, and also longlistings for the international Booker and Orange prizes. She now lives in Sydney.

Lau Siew Mei was born in 1968 and grew up in Singapore. After obtaining an arts degree at the National University of Singapore, she worked as a journalist and in 1994 migrated to Australia. Her novels have been shortlisted for several prizes, including the Christina Stead, the NSW Premier's and Queensland Literary Awards, and her stories have been published internationally in the USA, UK, Canada, Malaysia and Singapore. She lives in Brisbane where she has recently been studying Law, and her next forthcoming novel is The Immigrant.

Simone Lazaroo was born in 1961 to a Eurasian family in Singapore, and they migrated to Australia when she was a young child. Her novels have won the WA Premier's Literary prize three times: in 1995, 2000 and 2006. She lives in Fremantle and teaches Creative Writing at Murdoch University.

Chandani Lokugé was born in Sri Lanka and after completing an MA at Peradeniya University, came to Australia in 1987 on a Commonwealth Scholarship to complete a PhD at Flinders University. She is currently an Associate Professor at Monash University and Director of the Centre for Postcolonial Writing. Her first novel, If the Moon Smiled, was shortlisted for the NSW Premier's Prize for Best Novel in 2001. 
Hoa Pham was born in Tasmania to Vietnamese parents who had come to Australia to study. She is a psychologist and a writer. Vixen, her fourth novel, won the SMH Best Young Australian Novelists Award in 2000. The Other Shore, won the Viva Novella 2 prize in 2014, and Wave is being adapted into a film. She was a co-founder of Peril in 2007.

Alice Pung was born in Footscray, Melbourne; her heritage is Cambodian and Chinese. She works as a lawyer and has published a number of novels that have received short/longlistings for Premier's awards in Victoria and NSW, and the Stella prize; Laurinda received the Ethel Turner prize in 2016. She edited the widely-read and studied anthology, Growing Up Asian in Australia (2008).

Hsu Ming Teo was born in Malaysia in 1970 but moved to Sydney in 1977. She is currently an Associate Professor of Modern History at Macquarie University. Her first novel, Love and Vertigo won the Vogel award in 1999.

Chi Vu was born in Vietnam in 1973, and came to Australia by boat in 1979; she is a writer and producer. Her novel Anguli Ma was shortlisted for the NSW Premier's Award, and her Coloured Aliens played at the Melbourne International Comedy Festival in 2017. http://artsreview.com.au/on-the-couch-with-chi-vu/

Beth Yahp was born in Malaysia and came to Australia in 1984. She has lived in Sydney, Kuala Lumpur and Paris. The Crocodile Fury won the Victorian Premier's Prize for First Fiction and the NSW Ethnic Affairs Commission Award in Australia, and was also published in several European languages. She has taught creative writing for many years, and currently lectures in the Creative Writing program at the University of Sydney. She presented Elsewhere, a radio program for travellers on ABC Radio National (2010-11) and founded the popular Memoir Club at the Randwick Literary Institute in Sydney. 